\title{
Seasonal Changes in Trans-Aconitate and Mineral Composition of Crested Wheatgrass in Relation to Grass Tetany
}

\section{M. STUART, H. F. MAYLAND, AND D. L. GRUNES}

Highlight: Grass tetany (hypomagnesemia) frequently occurs from March through June in cattle grazing crested wheatgrass in western United States. High levels of transaconitate and/or citrate, $\mathrm{K}, \mathrm{K} /(\mathrm{Ca}+\mathrm{Mg})$ ratios and low $\mathrm{Mg}$ in the grass are implicated in the etiology of the disease. In the moist 1967 season, during periods of "flush" growth following warming trends, trans-aconitate and $\mathrm{K}$ increased while Ca and $\mathrm{Mg}$ decreased in crested wheatgrass. These characteristics may explain the incidence of grass tetany during periods of "flush" growth. During the dry 1968 season, these trends were not observed. Growth chamber studies confirmed some of the reasons for changes in crested wheatgrass composition observed in 1967 and 1968.

Grass tetany (hypomagnesemia), a metabolic disorder of ruminants, frequently occurs from March through June on pastures of crested wheatgrass (Agropyron desertorum) and other grasses in the western United States (Grunes et al., 1970). In the last 10 years at least 470 known cases of tetany and many suspected cases were noted in northern Nevada, mainly in the extreme

The authors are soil scientists, Agricultural Research Service, U. S. Department of Agriculture, located at, respectively, Soil and Water Research Division, Reno, Nevada; Snake River Conservation Research Center, Kimberly, Id aho; and U. S. Plant Soil and Nutrition Laboratory, Ithaca, New York.

The paper is a contribution of the Soil and Water Conserv. Res. Div., Agr. Res. Serv., U.S. Dep. Agr., in cooperation with the Nevada Agricultural Experiment Station, Reno, as journal Series No. 136.

Manuscript received February 28, 1972. northeastern part of the state (unpublished Nevada State Office, BLM Report). Most reported cases were on crested wheatgrass, but losses also happened on native grasses. Tetany occurs in northeastern Nevada in early spring or late winter when cows are fed grass hay. Hjerpe (1964) reports tetany to be a major problem in California, with losses estimated at 4,000 to 6,000 head during the winter of 1963-64 and sporadic losses reported annually. Losses also occur in Idaho and Utah. Tetany may be prevalent during the autumn months, especially on regrowth after late summdr showers.

Induction of the disorder involves many factors. Among factors that promote tetany are low temperatures or a change from low to high temperatures with rapid growth when moisture is adequate (Kemp and 't Hart, 1957). During dry years incidence of tetany is much lower. High rates of $\mathrm{K}$ and $\mathrm{N}$ fertilization and low forage $\mathrm{Mg}$ are also involved (Kemp, 1958, 1960). The Mg content of grass tetany-prone pastures is between $0.07 \%$ and $0.20 \%$ dry weight basis, with averages of $0.17 \%$ for the Netherlands (Kemp and 't Hart, 1957) and $0.145 \%$ for Scotland (Butler, 1963). The critical level is controlled by the relative availability of $\mathrm{Mg}$ to the animal. Ratios of $\mathrm{K} / \mathrm{Ca}+\mathrm{Mg}$ ) (expressed as $\mathrm{meq} / \mathrm{kg}$ ) greater than 2.2 have been related to the occurrence of tetany (Kemp and 't Hart, 1957).

More recently, trans-aconitate of $1 \%$ or more in grass has been associated with tetany (Burau and Stout, 1965; Stout et al., 1967). Also, the dietary intake of $1 \%$ citric acid, as sodium citrate, reduced the $\mathrm{Mg}$ concentration in the blood.serum of ruminants (Burt and Thomas, 1961). Bohman et al. (1969) induced tetany in cows by giving citric or trans-aconitic acid and $\mathrm{KC} 1$ as an oral drench. For a comprehensive review of grass tetany, the reader is referred to the article by Grunes et al. (1970). The objective of this study was to 
evaluate the effect of environmental temperatures on changes in transaconitate, $\mathrm{Mg}, \mathrm{Ca}$, and $\mathrm{K}$ in crested wheatgrass and relate such changes to the incidence of grass tetany on spring ranges in northern Nevada.

\section{Methods}

During April and May of 1967 and 1968 , crested wheatgrass samples were collected from a well established, nongrazed seeding at Orovada in Northwestern Nevada. Losses from grass tetany had occurred in this area in previous years. Sampling began when the blades were about $5 \mathrm{~cm}$ long and continued until the soft dough stage. About $100 \mathrm{~g}$ of fresh plant material were collected weekly by taking a few blades from randomly selected plants. The grass was cut from 2.5 to $5 \mathrm{~cm}$ above the ground. Samples were frozen with solid $\mathrm{CO}_{2}$ or liquid $\mathrm{N}_{2}$, subsequently freeze-dried and ground to pass a 40-mesh screen.

Sodium, $\mathrm{K}, \mathrm{Ca}$ and $\mathrm{Mg}$ were determined on nitric-perchloric acid digests of dried plant material by atomic absorption spectroscopy. Chlorides were extracted with $0.1 \mathrm{~N}$ nitric acid and determined potentiometrically (Brown and Jackson, 1955). Total aconitate was determined by a modification of a polarographic procedure (Burau, 1969). Fifty $\mathrm{ml}$ of extracting solution $\left(0.1 \quad \mathrm{M} \quad \mathrm{Na}_{2} \mathrm{HPO}_{4}-\right.$ $0.1 \mathrm{M} \mathrm{NH}_{4} \mathrm{Cl}, \mathrm{pH}$ 9.5) was added to 0.5 $\mathrm{g}$ of plant material and shaken for 1 hour in the presence of approximately $1 \mathrm{~g}$ of gas-produced carbon black. After filtering, a 10-ml aliquot of the extract was combined with $10 \mathrm{ml}$ of $0.5 \mathrm{~N} \mathrm{HCl}$ and made to a volume of $50 \mathrm{ml}$ with water. A $25-\mathrm{ml}$ aliquot was then placed in a polarographic electrolysis vessel, " $\mathrm{H}$ " form, and de-aerated with nitrogen. The diffusion current at -0.9 volt was measured and compared with a standard curve to give the concentration of total aconitate in the unknown.

Air temperatures were recorded on a thermograph in a standard U. S. Weather Bureau shelter $15 \mathrm{~cm}$ above the ground surface. The temperatures are shown as 5-day means. Rainfall data were taken from the U. S. Weather Bureau Station at Orovada approximately $2 \mathrm{~km}$ from the plots.

Soil samples were taken at $15-\mathrm{cm}$ increments to a depth of $45 \mathrm{~cm}$, dried and ground to pass a $2-\mathrm{mm}$ sieve. Each sample was extracted with neutral $1 \mathrm{M}$ ammonium acetate (Richards, 1954); the concentration of $\mathrm{Na}, \mathrm{K}, \mathrm{Ca}$ and $\mathrm{Mg}$ was determined by atomic absorption spectrophotometry. The $\mathrm{pH}$ of the saturated soil paste was measured with a glass electrode; soluble salts were estimated by electrical conductivity of extracts of saturated soil pastes (Richards, 1954).

In order to investigate the relation- hips among temperature, "flush" growth, and changes in elemental and trans-aconitate contents of crested wheatgrass, a growth chamber study was undertaken.

For growth chamber studies, eight crested wheatgrass seeds were planted in each of 42 black plastic pots, $12.7 \mathrm{~cm}$ diameter and $15 \mathrm{~cm}$ high. Each pot was filled with a potting mix consisting of six parts loam, one part expanded vermiculite, and one part peat moss. The soil was kept moist and left in the greenhouse about 12 weeks until the grass was 18 to $23 \mathrm{~cm}$ tall. These pots were then transferred to a temperature and light controlled growth chamber. Plants were left in the chamber with a light intensity of 21,500 lux and a 10-hour dark and 14-hour light period for 15 days. Temperature was programed for a minimum of $6^{\circ} \mathrm{C}$ about an hour before the light period started and for a peak of $27^{\circ} \mathrm{C}$ midway through the light period. Temperatures were programed to follow the regimen of a typical warm spring day at Orovada.

After the first 15-day period was over, the photoperiod was left the same, but light intensity was lowered to 10,750 lux. The temperature was programed to follow a typical cool, cloudy spring day at Orovada with a low of $-1^{\circ} \mathrm{C}$ and a high of $7^{\circ} \mathrm{C}$. This regimen continued for 18 days. On the 18 th day the grass was returned to the high light, high temperature regimen. Sufficient water was added to maintain good plant growth. Samples were taken periodically during the cool and warm periods by removing a few blades of grass from each pot. The grass was analyzed as previously described.

When the sampling period was over, the grass was clipped to a height of 2.5 $\mathrm{cm}$ and sprayed for aphids. Regrowth was not good because the grass appeared deficient in $P$ and $N$. Each pot was fertilized with $3 \mathrm{~g}$ of diammonium phosphate, equivalent to $502 \mathrm{~kg} / \mathrm{ha}$ of $\mathrm{N}$ and $556 \mathrm{~kg} / \mathrm{ha}$ of $\mathrm{P}$. The fertilized grass was grown under the high light, cool temperature regimen until the plants were 18 to $23 \mathrm{~cm}$ tall. The regimen was then changed to reduced light and cool temperatures for 17 days and then to high light and warm temperatures for the rest of the sampling period (30 days). Periodic samples were taken during both the cool and

Table 1. Ammonium acetate (1-molar) extractable cations, and cation changeable capacity (meq/100 g) Orovada, Nevada, 1967 and 1968.

\begin{tabular}{lcccrcc}
\hline \hline Location & Depth $(\mathrm{cm})$ & $\mathrm{Na}$ & $\mathrm{K}$ & $\mathrm{Ca}$ & $\mathrm{Mg}$ & Exc. cap. \\
\hline Orovada, 1967 & $0-15$ & 0.5 & 1.8 & 7.2 & 3.7 & 12.9 \\
& $15-30$ & 2.7 & 1.3 & 8.9 & 3.3 & 14.5 \\
& $30-45$ & 6.3 & 0.9 & 26.0 & 4.0 & 14.8 \\
Orovada, 1968 & $0-15$ & 1.8 & 1.8 & 9.3 & 3.0 & 14.8 \\
& $15-30$ & 5.1 & 1.2 & 10.3 & 2.9 & 15.1 \\
& $30-45$ & 12.5 & 0.6 & 22.8 & 2.5 & 14.7 \\
\hline
\end{tabular}

Mean annual rainfall at Orovada is $29.15 \mathrm{~cm}$ with a mean of $10.1 \mathrm{~cm}$ in March, April, and May. However, rainfall during the spring of 1967 was 2.9 greater than normal for March, April, and May. Soil moisture was adequate, and plants showed no water stress during the 1967 sampling season. The spring of 1968 was much drier than normal, following a dry winter. Precipitation totaled only $5.4 \mathrm{~cm}$ during March, April, and May. The majority of the precipitation, $2.6 \mathrm{~cm}$, occurred during the first 2 weeks of April. Grass showed water stress by the May 11, 1968, sampling.

Soils were derived from well-drained mixed alluvium, silty loam in texture, and were not strongly developed morphologically, although the $30-$ to $45-\mathrm{cm}$ depth was calcareous. The $\mathrm{pH}$ was approximately neutral (6.8 to 7.4). Soluble salts were low in the surface $15 \mathrm{~cm}$ but increased slightly with depth. Considerable volcanic ash was also present. Cations in the $1 \mathrm{M}$ ammonium acetate extracts and the cation exchange capacity are shown in Table 1. The 1968 samples were from a site adjacent to the 1967 site and illustrate some of the natural variability. Soil $\mathrm{K}$ and $\mathrm{Mg}$ appeared adequate for plant growth.

During the moist 1967 season the trans-aconitate and $\mathrm{K}$ levels of crested wheatgrass paralleled each other (Fig. 1). Changes in $\mathrm{K}$ correlated significantly with maximum temperature changes. Transaconitate almost correlated with temperature changes. When air temperatures increased in early May, $\mathrm{K}$ and transaconitate increased while $\mathrm{Ca}$ and $\mathrm{Mg}$ decreased. Using the $t$-distribution test (Snedecor, 1956) and ignoring the first two sampling dates when the blades were less than $5 \mathrm{~cm}, \mathrm{~K}$ and $\mathrm{T}$. A. were significantly (1\%) higher and $\mathrm{Ca}$ and $\mathrm{Mg}$ were significantly lower (1\%). At the beginning of the season, $\mathrm{Mg}$ values were above the $0.14 \%$ to $0.17 \% \mathrm{Mg}$ levels of the tetany- 
prone pastures of the Netherlands and Scotland. Magnesium reached tetanyprone levels $(0.09$ to $0.12 \%)$ following the increase in temperature.

The ratio of $\mathrm{K} /(\mathrm{Ca}+\mathrm{Mg})$ was low until the temperature increased and then rapidly increased to tetany-prone levels.

Following the increase in temperature, $\mathrm{K} /(\mathrm{Ca}+\mathrm{Mg})$ was significantly higher $(1 \%)$ than before the temperature increase. Chloride levels were $0.75 \%$ at the beginning of the season, fell to $0.5 \%$, and rose to $0.64 \%$ at the end of the season. Sodium was low, less than $0.09 \%$, throughout the season.

The rapid increase in blade length is indicative of the period of "flush" growth following the general rise in air temperature about May 5.

The dry 1968 season produced plant composition patterns that were different from those of the moist 1967 season (Fig. 2 ). Excluding the first sampling date, $K$ and trans-aconitate values tended to parallel each other until soil moisture was depleted during the first week in May. When the temperature increased, $K$ and trans-aconitate increased; but when moisture stress developed, trans-aconitate decreased. About a week later $\mathrm{K}$ also decreased. No significant difference was found in $\mathrm{K}$ or trans-aconitate between the cool and warm periods. There was no significant difference in trans-aconitate between the dry and wet years, but $\mathrm{K}$ was significantly (1\%) lower in the dry year.

Magnesium and $\mathrm{Ca}$ were significantly
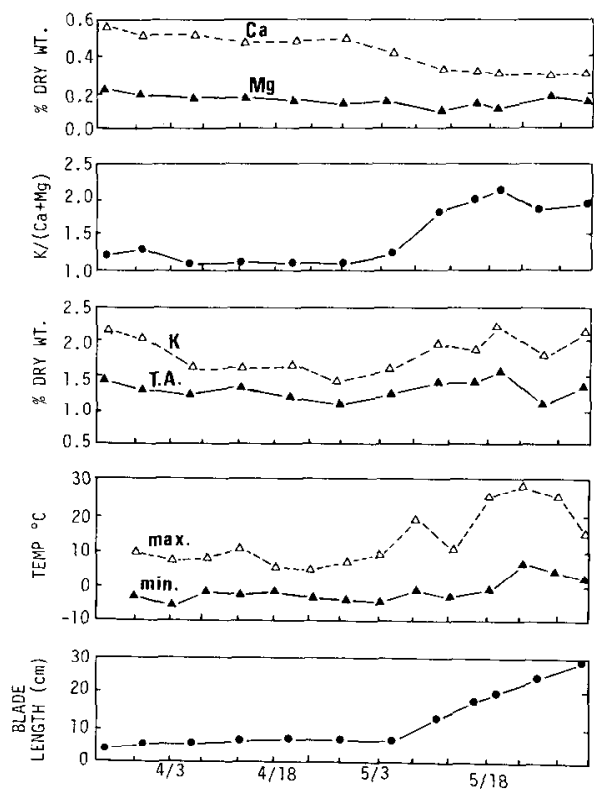

Fig. 1. Relation between air temperature $(15 \mathrm{~cm}$ above soil surface), $\mathrm{Ca}, \mathrm{Mg}, K$, transaconitate (T. A.), $\mathrm{K} /(\mathrm{Ca}+\mathrm{Mg})(\mathrm{meq} / \mathrm{kg})$ and blade length in crested wheatgrass at Orovada, Nev. Spring 1967.
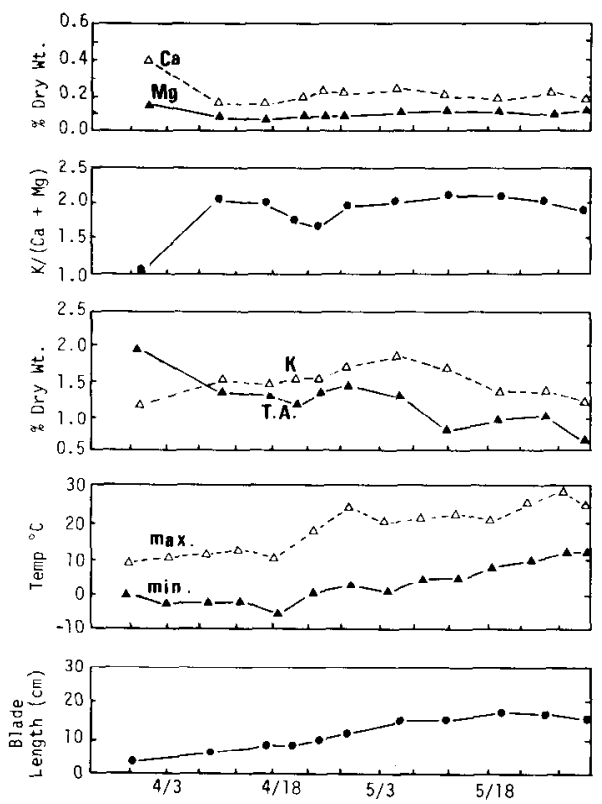

Fig. 2. Relation between air temperature $(15 \mathrm{~cm}$ above soil surface), $\mathrm{Ca}, \mathrm{Mg}, K$, transaconitate ( $T . A.), K /(C a+M g)$ (meq/ $\mathrm{kg}$ ) and blade length in crested wheatgrass at Orovada, Nev. Spring 1968.

(1\%) lower during the dry 1968 season, but no difference was found between the cool and warm periods. The $\mathrm{K} /(\mathrm{Ca}+\mathrm{Mg})$ ratios reached a peak at the beginning of the season and declined slightly when the grass showed moisture stress. The ratios never reached more than 2.0 , and there was no significant difference between the cool and warm period in the dry year. There was also no significant difference in maximum $\mathrm{K} /(\mathrm{Ca}+\mathrm{Mg})$ ratios in the wet (1967) and dry year (1968). Chlorides were slightly lower (approx. $0.5 \%$ ) than in the wet year and remained essentially unchanged throughout the scason. Sodium was also lower than in the previous season (less than $0.04 \%$ ) and remained essentially constant.

Blade length did not increase as rapidly and was not as great following the temperature increase in 1968 as in 1967 because moisture stress symptoms had begun to develop. Crested wheatgrass did not show any sustained period of "flush" growth in 1968.

In the growth chamber experiments, $\mathrm{Ca}$ and $\mathrm{Mg}$ in both the fertilized and nonfertilized crested wheatgrass decreased about 6 to 10 days after temperature and light had been increased (Fig. 3). The difference in $\mathrm{Ca}$ and $\mathrm{Mg}$ between the cool and warm periods were significant (1\%) for the nonfertilized crested wheatgrass. The differences were also significant at the $1 \%$ level for $\mathrm{Ca}$ and significant at the $5 \%$ level for $\mathrm{Mg}$ in the fertilized crested wheatgrass. The Ca concentration of the fertilized grass dropped about 3 days sooner than in the nonfertilized grass. The change in $\mathrm{Mg}$ was not as great as in $\mathrm{Ca}$, but $\mathrm{Mg}$ concentration of both the fertilized and nonfertilized grass was lowest about 14 days after temperature was increased.

As the cool period continued, $\mathrm{K}$ became progressively lower in both the fertilized and nonfertilized grass. About 6 days after temperature and light were increased, $K$ increased rapidly in the fertilized grass and remained about the same in the unfertilized. In the fertilized grass, $\mathrm{K}$ was significantly higher $(5 \%)$ in the warm period; in the nonfertilized grass, the reverse was found. Transaconitate concentration also increased about 6 days after temperature and light were increased. The differences in transaconitate between the cool and the warm periods were significant in the unfertilized grass but not in the fertilized grass. Potassium and trans-aconitate concentrations tended to parallel each other in fertilized grass.

The ratio of $\mathrm{K} /(\mathrm{Ca}+\mathrm{Mg})$ also increased between 6 to 10 days after temperature and light were increased in the fertilized and nonfertilized grass. The $\mathrm{K} /(\mathrm{Ca}+\mathrm{Mg})$ was significantly higher (nonfertilized 5\% level, fertilized 1\% level) in the warm period. In the fertilized grass, the ratio increased more rapidly and reached a high point of 4.0 in about 15 days. After the peak was reached, the ratio dropped to aboul 3.5 and stayed there for the remainder of the experiment.

\section{Discussion}

During 1967, outbreaks of grass tetany occurred the week of May 16 in northern Nevada (about $25 \mathrm{~km}$ north of the plots) and southern Idaho. This was the first week with minimum temperatures above $0^{\circ} \mathrm{C}$. A few cases of tetany are normally reported each year on seedings adjacent to the sample plots. In 1967, ranchers in this area delayed turn-out until the tetany season had passed and thus avoided the possibility of high death losses. No cases of tetany were reported during the dry spring of 1968 in the Orovada area. However, in the wetter parts of northern Nevada and southern Idaho, outbreaks of tetany were reported shortly after May 1 , when temperatures started to rise.

In the moist spring of 1967, the tetany-prone period began about a week after the temperature changed from cool to warm. At this time some of the factors 


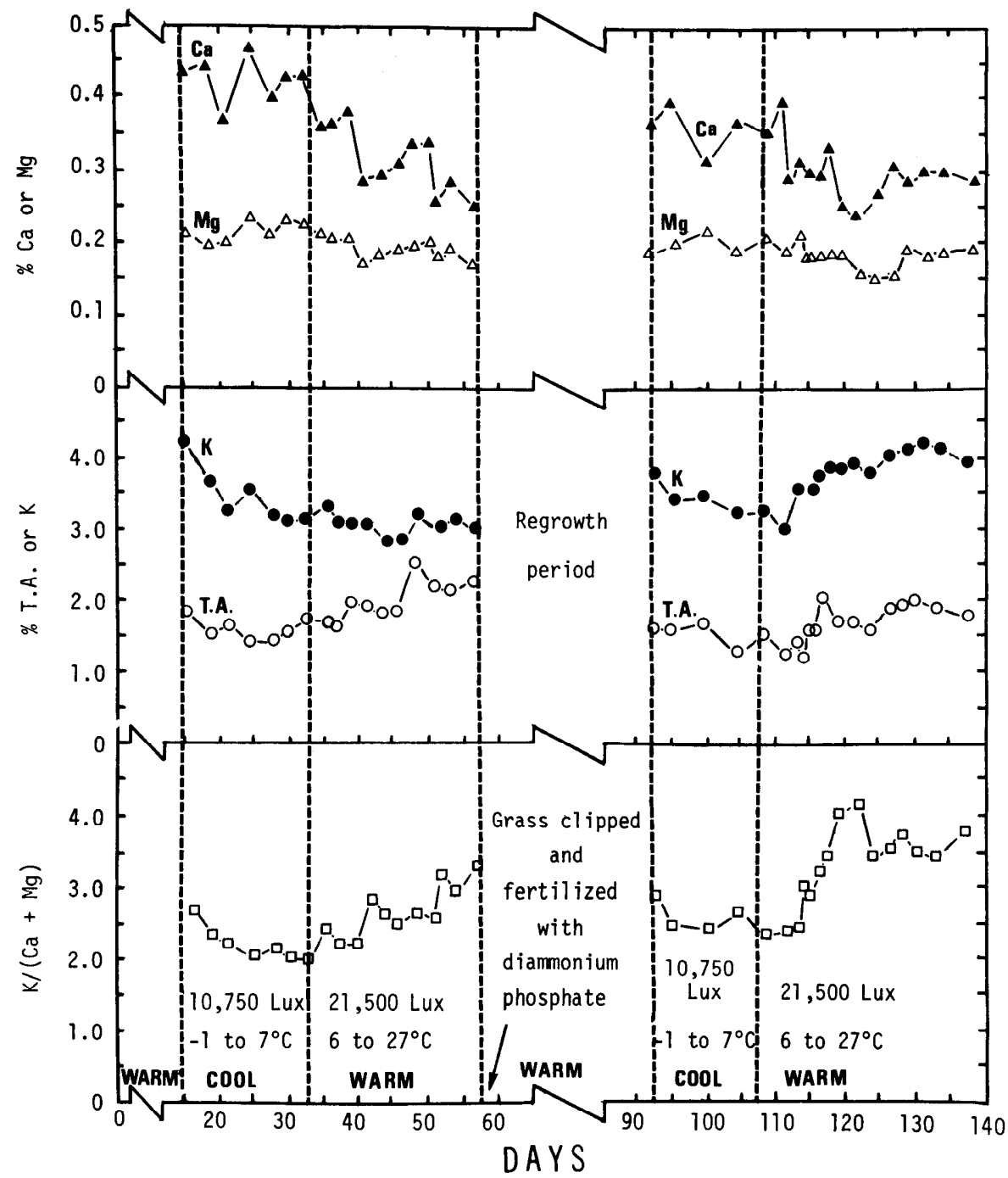

involved in the induction of grass tetany were optimal: high $\mathrm{K}$ and trans-aconitate levels, low $\mathrm{Ca}$ and $\mathrm{Mg}$, and a rapid increase in the ratio of $\mathrm{K} /(\mathrm{Ca}+\mathrm{Mg})$. This occurred at the same time as a period of "flush" growth induced by ample moisture and rising temperatures.

In the dry spring of 1968 , no period of "flush" growth was observed and no tetany was reported in the Orovada area. Potassium and trans-aconitate declined as moisture became limiting, and $\mathrm{Ca}$ and $\mathrm{Mg}$ were low. The ratio of $\mathrm{K} /(\mathrm{Ca}+\mathrm{Mg})$ was consistently rather high as a result of low $\mathrm{Ca}$ and $\mathrm{Mg}$ values.

Soil contained ample $\mathrm{Mg}$, but crested wheatgrass from the Orovada site was low in Mg. Similar results were obtained for samples collected throughout northern Nevada (unpublished data of the authors). Apparently, crested wheatgrass and other grasses (unpublished data of the authors) are unable to accumulate concentrations of $\mathrm{Mg}$ required for good animal nutrition, even though the soils

in elemental concentration, rather than particular level. We hypothesized that tetany did not occur in 1968 because there was no rapid change in the ratio even though the ratio was high throughgrass tetany in cattle grazing rapidly growing crested wheatgrass following a change from cool to warm temperatures
Fig. 3. Changes in $\mathrm{Ca}, \mathrm{Mg}, \mathrm{K}$, trans-aconitate (T. A.), and $\mathrm{K} /(\mathrm{Ca}+\mathrm{Mg})(\mathrm{meq} / \mathrm{kg})$ in crested wheatgrass grown in a growth chamber, when changed from a cool ( $-1 \mathrm{C}$ to $7 \mathrm{C})$ low light $(10,750$ lux) regimen to a warm (6 C to $27 \mathrm{C})$, high light $(21,500$ lux) regimen. After the first cycle, grass was clipped and fertilized with diamonium phosphate.

probably results from optimization of tetany inciting factors, in addition to those explained by the changes in elemental content (Grunes et al., 1970).

\section{Literature Cited}

Bohman, V. R., A. L. Lesperance, G. D. Harding, and D. L. Grunes. 1969. Induction of experimental tetany in cattle. J. Anim. Sci. 29:99-102.

Brown, J. G., and R. K. Jackson. 1955. A note on the potentiometric determination of chloride. Amer. Soc. Hort. Sci. Proc. 65:187.

Burau, R. G. 1969. Polarographic estimation of aconitates in plant materials. J. Agr. Food Chem. 17:1332-1334.

Burau, R. G., and P. R. Stout. 1965. Transaconitic acid in range grasses in the early spring. Science 150:766-767.

Burt, A. W. A., and D. C. Thomas. 1961. Dietary citrate and hypomagnesemia in the ruminant. Nature 192:1193.

Butler, E. J. 1963. The mineral element content of spring pasture in relation to the occurrence of grass tetany and hypomagnesemia in dairy cows. J. Agr. Sci. 60:329-340.

Grunes, D. L., P. R. Stout, and J. R. Brownell. 1970. Grass tetany of ruminants. Advancc. Agron. 22:331-374.

Hjerpe, C. A. 1964. Grass tetany in California cattle. J. Amer. Vet. Med. Ass. 144:1406.

Kemp, A. 1958. Influence of fertilizer treatment of grass lands on the incidence of hypomagnesemia and hypomagnesemic tetany in milking cows. Neth. J. Agr. Sci. 6:281-297.

Kemp, A. 1960. Hypomagnesaemia in milking cows: The response of serum magnesium to alterations in herbage composition resulting from potash and nitrogen dressings on pasture. Neth. J. Agr. Sci. 8:281-304.

Kemp, A., and M. L. 't Hart. 1957. Grass tetany in milking grazing cows. Neth. J. Agr. Sci. 5:4-17. out the entire period. The prevalence of
Richards, L. A., ed. 1954. Diagnosis and improvement of saline and alkali soils. U. S. Dep. Agr. Handbook 60.

Snedecor, G. W. 1956. Statistical methods. 5th ed. The Iowa State College Press, Ames, Iowa. $534 \mathrm{p}$.

Stout, P. R., J. Brownell, and R. G. Burau. 1967. Occurrences of trans-aconitate in range forage species. Agron. J. 59:21-24. 